\title{
DOMESTIC WASTEWATER EFFECTING ON PHYSICO-CHEMICAL PROPERTIES OF BATHI LAKE, DAVANGERE CITY, KARNATAKA
}

\author{
Padmini V N $\mathbf{1}^{1}$ H.B Aravinda ${ }^{2}$ \\ ${ }^{1}$ Student, Department of Civil Engineering, B.I.E.T., Davangere-577004 \\ ${ }^{2}$ Professor \& Head, Department of Civil Engineering, B.I.E.T., Davangere-577004
}

\begin{abstract}
In the present study, the work reveals about how the domestic wastewater is contaminating the Bathi lake, located in Davangere city also to know how it is effecting the physical and chemical parameters of the lake. They include pH, Electrical Conductivity, turbidity, Total Hardness, Calcium, Magnesium, chloride, Total Dissolved Solids, Dissolved Oxygen, Biological Oxygen Demand, Chemical Oxygen Demand, Sodium and potassium. The work was carried out during January 2016 to April 2016 for four months. Four stations have chosen in the lake. Station 1 -Domestic wastewater entering the lake. Station 2 -Domestic wastewater joining the lake. Station 3 -Domestic wastewater diluted with the lake which is far away from station 2. Station 4 - The lake water is taken. The results were compared WHO standards and BIS and some of the parameters were crossing the desired limits. Hence the work concludes that the quality of lake is poor and is unsuitable for human consumption.
\end{abstract}

Keywords: Lake, Domestic Wastewater, Physico-Chemical Parameters.

\section{INTRODUCTION}

Water is one of the most vital natural resources in the world for human, animals and plant consumption. Water can be seen on oceans, rivers, reservoirs, streams and lakes etc. Such water may be contaminated by discharging domestic waste, industrial water, agricultural activities, rainfall-runoff and erosion etc. They may pollute the water bodies by physical, chemical and biological means and finally become unfit for human consumption and drinking purpose to the water body and adversely affects the natural environment.

\subsection{Wastewater}

The source of wastewater is the combination of domestic, industrial, commercial or agricultural activities, surface runoff, sewer inflow or infiltration.

\subsection{Lake}

Lake is naturally formed waterbody with variable size surrounded by land. Lakes are deeper than ponds. They are found in mountainous areas, rift zones and areas ongoing glaciations. Glob is covered with water about $75 \%$ and this water is of saline. Less than $5 \%$ is of the fresh water and is available in the icecaps, glaciers and groundwater. Water is present in abundant quantities and under the surface but less than $1 \%$ of it is liquid fresh water. Earth's water is estimated about 1.4 billion cubic kilometer of water, it is in oceans or in frozen in polar ice caps and glaciers. Ocean water consists of $35 \mathrm{gm} / \mathrm{lts}$ of dissolved minerals or salts. These kinds of water is unfit for drinking.

Due to developing population, urbanization, agricultural activities and industrialization etc. have made surface water pollution to a greater extent, thereby reducing the quality of water bodies and availability of drinking water and hence it makes unfit for human consumption. The objective of the study is to analyse the physico-chemical characteristics of Bathi Lake. To determine the water quality and to ensure a safe environment for the sustenance of life.

\subsection{Study Area}

Davangere is the district i.e. located in central part of Karnataka and covers an area about 15645 sq.km

Bathi Lake: Bathi lake is situated towards north of Davangere and it is $3 \mathrm{~km}$ far away from Davangere. Bathi lake is perennial and fresh water body. The water body covers about an 74 acres of total area. It lies in between $75^{0} 30^{\prime}$ to $76^{0} 30^{\prime}$ of east longitude and $14^{0} 14^{\prime}$ to $14^{0} 31^{\prime}$ of north latitude. Rain water is the source for Bathi lake, total bund length is $880 \mathrm{mts}$, full supply depth $6.5 \mathrm{ft}$ and the capacity of the lake is 14.3 MCFT. This lake also has been encouraged for agricultural practices.

\section{MATERIALS AND METHODOLOGY}

The instruments used in the present study are: $\mathrm{pH}$ meter- for determining $\mathrm{pH}$, Conductivity meter for determining the Electrical Conductivity and Total Dissolved Solids, Turbidity meter for determining Turbidity and Flame photometer for determining Sodium and Potassium.

Sample collection: The samples are taken in a clean polythene bottles with air tight caps and then stored in laboratory for analysis. Four sampling stations have choosen i.e.

Station 1 - Domestic wastewater entering the lake.

Station 2 - Domestic wastewater joining the lake.

Station 3 -Domestic wastewater is diluted and flowing along the lake at a point farther than station 2 .

Station 4 - lake water. 
In the present study grab sampling is selected. The sampling is collected at a particular place and time. It represents a snapshot in both space and time of a sampling area. Grab sampling is chosen at particular location, depth and time.

\section{RESULTS AND DISCUSSIONS}

$\mathrm{pH}$ : It is a negative logarithm of concentration of hydrogen ion. It measures alkalinity and acidity of the solution. The $\mathrm{pH}$ mean values of four stations $\mathrm{S} 1, \mathrm{~S} 2, \mathrm{~S} 3$ and $\mathrm{S} 4$ are found to be $7.3,7.638,7.343$ and 7.212 They are almost neutral and slightly alkaline in nature.

Electrical Conductivity: It is the ability of the water conduct an electric current. The conductivity of four stations S1, S2, $\mathrm{S} 3$ and $\mathrm{S} 4$ are $477.47 \mu \mathrm{S} / \mathrm{cm}, 479.32 \mu \mathrm{S} / \mathrm{cm}, 408.62 \mu \mathrm{S} / \mathrm{cm}$ and $287.73 \mu \mathrm{S} / \mathrm{cm}$. The values of S1, S2 and S3 are higher indicates that the solution contains increased number of ions.

Turbidity: The appearance of the water is cloudiness or muddiness and when light is allowed to pass through such solution, it gets scattered and this affect the aquatic life. During the study period the recorded values are $7.8 \mathrm{NTU}$, 5.8 NTU, 6 NTU and 5.7 NTU of S1, S2, S3 and S4 respectively.

Total Hardness: It is the ability of water to produce lathering of soap. It includes complex mixtures of anions and cations. During the study period recorded values are $137 \mathrm{mg} / \mathrm{lt}$, $133.37 \mathrm{mg} / \mathrm{lt}, 128.12 \mathrm{mg} / \mathrm{lt}$ and $121.87 \mathrm{mg} / \mathrm{lt}$ of S1, S2, S3 and $\mathrm{S} 4$ respectively.

Calcium: Calcium adds to the total hardness of water. The results of S1, S2, S3 and S4 are $74.25 \mathrm{mg} / \mathrm{lt}, 73.875 \mathrm{mg} / \mathrm{lt}$, $70.12 \mathrm{mg} / \mathrm{lt}$ and $67.5 \mathrm{mg} / \mathrm{lt}$. Calcium is caused by the greater portion of hardness occurring in nature.

Magnesium: $\mathrm{Mg}$ also adds to the total hardness of water. The values of S1, S2, S3 and S4 are $63 \mathrm{mg} / \mathrm{lt}, 60.5 \mathrm{mg} / \mathrm{lt}$, $60.5 \mathrm{mg} / \mathrm{lt}$ and $55.37 \mathrm{mg} / \mathrm{lt}$. These are higher than the desired limit and is because the greater of hardness is occurring in nature.
Chloride: Clia an anion and can be seen in all kind of natural water. $\mathrm{Cl}$ values are $58.22 \mathrm{mg} / \mathrm{lt}, 51.1 \mathrm{mg} / \mathrm{lt}, 40.975 \mathrm{mg} / \mathrm{lt}$ and $32.475 \mathrm{mg} / \mathrm{lt}$ of S1, S2, S3 and S4 respectively.

Alkalinity: It indicates the neutralization of hydrogen ion. The results of S1, S2, S3 and S4 are $102.8 \mathrm{mg} / \mathrm{lt}, 97.75$ $\mathrm{mg} / \mathrm{lt}, 84.3 \mathrm{mg} / \mathrm{lt}$ and $82.8 \mathrm{mg} / \mathrm{lt}$.

TDS: they are the dissolved inorganic mineral content present in water. The results of S1, S2, S3 and S4 are $563.7 \mathrm{mg} / \mathrm{lt}, 420.4 \mathrm{mg} / \mathrm{lt}, 414 \mathrm{mg} / \mathrm{lt}$ and $341.5 \mathrm{mg} / \mathrm{lt}$. The results of $\mathrm{S} 1$ is high and crossing the desired limit because of the solids present in domestic wastewater entering into the lake has significant influence on TDS.

TSS: These are total solids contributing to the water except that of dissolved solids. The results of S1, S2, S3 and S4 are $425.06 \mathrm{mg} / \mathrm{lt}, \quad 296.07 \mathrm{mg} / \mathrm{lt}, 228.128 \mathrm{mg} / \mathrm{lt}$ and $77 \mathrm{mg} / \mathrm{lt}$ respectively.

DO: It represents the amount of oxygen dissolved in water. The results of S1, S2, S3 and S4 are $5.87 \mathrm{mg} / \mathrm{lt}, 6.08 \mathrm{mg} / \mathrm{lt}$, $6.62 \mathrm{mg} / \mathrm{lt}$ and $6.23 \mathrm{mg} / \mathrm{lt}$.

BOD: The amount of oxygen required by the microorganisms to decompose the organic matter. The results of S1, S2, S3 and S4 are $8.89 \mathrm{mg} / \mathrm{lt}, 8.7 \mathrm{mg} / \mathrm{lt}, 8.4$ $\mathrm{mg} / \mathrm{lt}$ and $7.6 \mathrm{mg} / \mathrm{lt}$. Since the values are higher than the desired limits it is due to the organic loading of the lake.

COD: It is the oxygen equivalent to the organic matter in presence of strong oxidizing agent. The results of S1, S2, S3 and $\mathrm{S} 4$ are $28.66 \mathrm{mg} / \mathrm{lt}, 28.13 \mathrm{mg} / \mathrm{lt}, 28.72 \mathrm{mg} / \mathrm{lt}$ and 28.03 $\mathrm{mg} / \mathrm{lt}$.

Sodium: It is a mineral that is highly soluble in water. The results of S1, S2, S3 and S4 are $88.06 \mathrm{mg} / \mathrm{lt}, 79.4 \mathrm{mg} / \mathrm{lt}, 75.5$ $\mathrm{mg} / \mathrm{lt}$ and $59.3 \mathrm{mg} / \mathrm{lt}$. It results that sodium which is present in domestic wastewater entering and contributing to the lake.

Potassium: It is a mineral alike of sodium and present in lower concentrations in natural waters. The results of $\mathrm{S} 1$, $\mathrm{S} 2, \mathrm{~S} 3$ and S4 are $8.7 \mathrm{mg} / \mathrm{lt}, 8.5 \mathrm{mg} / \mathrm{lt}, 7.5 \mathrm{mg} / \mathrm{lt}$ and $7 \mathrm{mg} / \mathrm{lt}$.

Table - 1: Analysis of Physico-chemical parameters recorded at station-1

\begin{tabular}{|l|l|l|l|l|l|l|l|l|}
\hline Parameter & Jan 03 & Jan 15 & Feb 03 & Feb 15 & Mar 03 & Mar 15 & Apr 03 & Apr 15 \\
\hline pH & 7.05 & 7.2 & 7.06 & 7.35 & 7.2 & 7.18 & 7.8 & 7.5 \\
\hline EC & 104.5 & 193 & 259 & 289.3 & 551 & 851 & 641 & 931 \\
\hline Turbidity & 7.1 & 7.9 & 8.1 & 8.6 & 8.1 & 7.1 & 7.9 & 7.6147 \\
\hline TH & 147 & 143 & 141 & 140 & 136 & 131 & 127 & 125 \\
\hline Ca & 86 & 81 & 76 & 71 & 71 & 73 & 69 & 67 \\
\hline Mg & 62 & 63 & 66 & 70 & 66 & 59 & 59 & 59 \\
\hline Chloride & 65.8 & 56 & 54 & 61 & 59 & 56 & 62 & 53 \\
\hline Alkalinity & 109 & 101 & 111 & 99 & 106 & 97 & 98 & 101 \\
\hline TDS & 651 & 602 & 551 & 571 & 582 & 521 & 526 & 506 \\
\hline TSS & 125 & 126.5 & 127 & 498 & 680 & 518 & 638 & 688 \\
\hline DO & 5.6 & 5.8 & 5.1 & 5.8 & 6.5 & 6.8 & 5.6 & 5.5 \\
\hline BOD & 10.3 & 10.6 & 8.6 & 9.3 & 8.6 & 8.1 & 8.3 & 8.1 \\
\hline COD & 30.1 & 29.9 & 28.1 & 28.6 & 28.1 & 29.3 & 28.1 & 27.1 \\
\hline
\end{tabular}




\begin{tabular}{|l|l|l|l|l|l|l|l|l|}
\hline $\mathrm{Na}$ & 97.7 & 91.05 & 89.7 & 86.6 & 88.5 & 83.1 & 89.5 & 78.4 \\
\hline $\mathrm{K}$ & 9.5 & 9.8 & 8.5 & 8.3 & 8.4 & 7.8 & 8.2 & 9 \\
\hline
\end{tabular}

Table - 2: Analysis of Physico-chemical parameters recorded at station-2

\begin{tabular}{|l|l|l|l|l|l|l|l|l|}
\hline Parameter & Jan 03 & Jan 15 & Feb 03 & Feb 15 & Mar 03 & Mar 15 & Apr 03 & Apr 15 \\
\hline pH & 6.95 & 7.8 & 7.5 & 8.2 & 7.08 & 8.2 & 7.8 & 7.58 \\
\hline EC & 541.5 & 351 & 544 & 344 & 579 & 518 & 406 & 551 \\
\hline Turbidity & 6 & 5.1 & 6.6 & 6.1 & 6.1 & 6.1 & 5.1 & 5.9 \\
\hline TH & 143 & 149 & 136 & 141 & 128 & 137 & 121 & 122 \\
\hline Ca & 82 & 76 & 74 & 76 & 69 & 77 & 71 & 66 \\
\hline Mg & 62 & 64 & 63 & 66 & 60 & 61 & 51 & 57 \\
\hline Chloride & 56.2 & 53 & 49 & 46.6 & 56 & 57 & 48 & 43 \\
\hline Alkalinity & 95 & 97 & 99 & 101 & 96 & 98 & 97 & 99 \\
\hline TDS & 481 & 421 & 381 & 411 & 406 & 416 & 426 & 421 \\
\hline TSS & 120.8 & 121 & 130.8 & 295 & 428 & 335 & 430 & 508 \\
\hline DO & 5.9 & 5.9 & 6.3 & 6.2 & 6.8 & 6.3 & 5.8 & 5.5 \\
\hline BOD & 9.6 & 9.1 & 9.3 & 8.6 & 8.4 & 8.4 & 8.1 & 8.1 \\
\hline COD & 29.7 & 28.7 & 28.3 & 27.6 & 27.1 & 27.3 & 28.1 & 28.3 \\
\hline Na & 85.2 & 76.5 & 79 & 86.8 & 83 & 79 & 66 & 79 \\
\hline K & 9 & 9.2 & 8.5 & 8.1 & 9 & 8.3 & 7.5 & 8.4 \\
\hline
\end{tabular}

Table - 3: Analysis of Physico-chemical parameters recorded at station-3

\begin{tabular}{|l|l|l|l|l|l|l|l|l|}
\hline Parameter & Jan 03 & Jan 15 & Feb 03 & Feb 15 & Mar 03 & Mar 15 & Apr 03 & Apr 15 \\
\hline $\mathrm{pH}$ & 7.5 & 6.8 & 7.0 & 7.3 & 7.05 & 7.7 & 7.6 & 7.8 \\
\hline EC & 506 & 416 & 317 & 517 & 305 & 376 & 451 & 381 \\
\hline Turbidity & 4.9 & 4.1 & 5.1 & 6.1 & 7.1 & 6.6 & 7.1 & 8.1 \\
\hline TH & 141 & 139 & 135 & 131 & 127 & 117 & 119 & 116 \\
\hline Ca & 81 & 76 & 71 & 71 & 69 & 66 & 64 & 63 \\
\hline Mg & 61 & 64 & 65 & 61 & 63 & 62 & 54 & 54 \\
\hline Chloride & 46 & 44 & 41 & 36.8 & 37 & 43 & 39 & 41 \\
\hline Alkalinity & 88 & 81 & 79 & 99 & 76 & 86 & 84 & 81 \\
\hline TDS & 411 & 426 & 416 & 405 & 409 & 413 & 422 & 409 \\
\hline TSS & 121 & 120 & 123 & 320 & 210 & 220 & 305 & 406 \\
\hline DO & 6.4 & 6.3 & 6.8 & 6.4 & 6.9 & 6.1 & 7 & 7.1 \\
\hline BOD & 8.6 & 8.7 & 8.1 & 8.5 & 8.3 & 8.4 & 8.6 & 8.1 \\
\hline COD & 29.6 & 28.1 & 28.6 & 29.1 & 29.3 & 28.6 & 28.4 & 28.1 \\
\hline Na & 76.2 & 86.1 & 76 & 66.8 & 79.2 & 71.1 & 79.2 & 69.2 \\
\hline K & 8.3 & 8.1 & 6.5 & 6.3 & 8.2 & 7.8 & 7.2 & 8.1 \\
\hline
\end{tabular}

Table - 4: Analysis of Physico-chemical parameters recorded at station-4

\begin{tabular}{|l|l|l|l|l|l|l|l|l|}
\hline Parameter & Jan 03 & Jan 15 & Feb 03 & Feb 15 & Mar 03 & Mar 15 & Apr 03 & Apr 15 \\
\hline $\mathrm{pH}$ & 7.15 & 7.3 & 7.08 & 7.28 & 7.32 & 7.52 & 7.05 & 7 \\
\hline EC & 136.3 & 141 & 109.3 & 109.3 & 631 & 572 & 351 & 236 \\
\hline Turbidity & 4.1 & 4.6 & 5.1 & 6.1 & 5.1 & 6.3 & 8.1 & 7.1 \\
\hline $\mathrm{TH}$ & 139 & 127 & 125 & 120 & 121 & 117 & 111 & 115 \\
\hline $\mathrm{Ca}$ & 76 & 69 & 69 & 66 & 65 & 66 & 65 & 64 \\
\hline $\mathrm{Mg}$ & 64 & 59 & 57 & 55 & 57 & 52 & 47 & 52 \\
\hline Chloride & 39 & 36 & 33 & 31.8 & 36 & 29 & 29 & 26 \\
\hline Alkalinity & 84 & 86 & 80 & 96 & 77 & 81 & 82 & 76 \\
\hline TDS & 381 & 386 & 372 & 311 & 326 & 316 & 319 & 321 \\
\hline TSS & 15 & 16 & 18 & 135 & 110 & 96 & 112 & 114 \\
\hline DO & 6.9 & 6.6 & 6.5 & 5.9 & 6.4 & 5.6 & 5.9 & 6.1 \\
\hline BOD & 8.1 & 8.3 & 8.6 & 7.9 & 8.5 & 8.1 & 8.1 & 8.2 \\
\hline COD & 29.1 & 28.3 & 28.2 & 28.5 & 28.5 & 28.1 & 27.3 & 27.1 \\
\hline Na & 54.2 & 55.5 & 60.5 & 68.5 & 61.1 & 59.2 & 59.1 & 56.2 \\
\hline K & 8.1 & 8.5 & 7.5 & 6.2 & 6.4 & 6.3 & 6 & 7.1 \\
\hline
\end{tabular}




\section{CONCLUSION}

In this present work, the study reveals about physicochemical characteristics of Bathi lake. The main aim of the study is to analyze the physical and chemical characteristics of Bathi lake and to understand how the domestic wastewater is effecting on the quality of lake. The lake is polluted due to entry of domestic wastewater into lake and also the agricultural activities around the lake. The results from the study points out that the stations 1,2 and 3 are polluted compared to station 4 . This is due to the discharge of the domestic wastewater into the lake. The impurities present in domestic wastewater is entering and contaminating with the impurities present in the Bathi lake. This concludes that the lake water is unsuitable for human consumption and hence it cannot be used without any proper treatment.

\section{REFERENCES}

[1] Arcadio P and Gregoria A (2003). Physical and Chemical Treatment of Water and Waste water. Sincero, A.P and G.A. Sincero. U.K.

[2] Chandra Shekhar M (1997). Journal of Water Science and Technology.

[3] Chang, H., (2008). Spatial analysis of water quality trends in the Han River basin, South Korea.

[4] DubeySavita (2013) Analysis of Physico-Chemical Parameters of Kshiprariver Water at Ujjain, India.

[5] David, C., (2004). Small Water Supplies. Cromwell Press, Trowbridge, Wiltshire. India.

[6] FtsumGebreyohannes, AbrahaGebrekidan, AmanualHadera and SamuaelEstifanos (2015) Investigations of Physico-Chemical Parameters and its Pollution Implications of Elala River, Mekelle, Tigray, Ethiopia

[7] Jain and Jain (2007) Engineering Chemistry, 15th edition, DhanapatRai Publishing Company, New Delhi.

[8] Patil. P.N, Sawant. D.V, Deshmukh. R.N (2012). Physico-chemical parameters for testing of water - A review

[9] Purushottam J. Puri, M.K.N. Yenkie, D. G. Battalwar, Nilesh V. Gandhare and Dewanand B. Dhanorkar(2010) study and interpretation of physico-chemical characteristic of lake water quality in nagpur city (india).

[10] R. Sivakumar, R. Mohanraj and P. A. Azeez(2000). Physico-Chemical analysis of Water Sources of Ooty, South India

[11] Shukla GS, Kant R and Tripathi BD (1989). Ecological investigation of physico-chemical characteristics and phytoplankton productivity of river Ganga at Varanasi.

[12] Sonune NA, Mungal NA and Kamble SP (2015) Study of physico-chemical characteristics of domestic wastewater in Vishnupuri, Nanded, India

[13] Thorvat A.R., Sonaje N.P., Mujumdar M.M. and Swami V.A.(2012) A Study on the Physico-Chemical Characteristics of Panchaganga River in Kolhapur City, MS, INDIA
[14] T. ParameswaraNaik, K. V. ajayan and G.H. Lokesh(2012)physico-chemical characteristics of kunigal lake in tumkur district, karnataka, india

[15] V. Jayalakshmi, N. Lakshmi* and M.A. SingaraCharya(2011)Assessment of PhysicoChemical Parameters of Water and Waste Waters in and Around Vijayawada 